\title{
NATURAL TRYPANOSOMA CRUZI INFECTION IN DOGS OF ENDEMIC AREAS OF THE ARGENTINE REPUBLIC (1)
}

\section{SUMMARY}

The population dynamics and the prevalence of chagasic infection of 352 dogs living in 108 rural houses infested by triatomines were studied. The region was divided into three sections according to increasing distances to an urban area. Each animal was identified by means of its particular characteristics and built, and its owners gave information about its habits. By means of xenodiagnosis, serology and ECG studies, prevalences of infection, parasitological-serological correlation, percentage of altered electrocardiographic outlines and percentage of houses with parasitemic dogs, were determined.

The rural area showed a characteristic T. cruzi infection pattern and differences in the canine population parameters with respect to the other areas were observed: a higher proportion of puppies than adult dogs, a more sedentary population. higher prevalences of infection, as measured by xenodiagnosis, in dogs, and the highest proportion of bedroom insects infected with $\mathbf{T}$. cruzi.

It is assumed that the sedentary characteristics of the human population in that rural area impinge in the blood offer to the triatomine population, and the high percentage of parasitemic dogs of the area. contribute to the rise of "kissing ougs" infected with $\mathbf{T}$. cruzi found in bedrooms.

KEY WORDS: Chagas' disease; Epidemiology: Dogs: Trypanosoma cruzi.

\section{INTRODUCTION}

The knowledge of $\mathrm{t}^{\mathrm{T}}$ a dynamics of transmission of Trypanosoma cruzi in the domestic rural environment is essential for the application of measures tending to diminish or abolish inciden ces of infection in humans and animals.

The elevated frequency of parasitemic dogs $\mathrm{s}^{6}$ ${ }^{27}$ and the detection of high proportions of proteins derived from canine blood in the contents of Triatoma infestans promesenteron ${ }^{26}$, is ev1 dence of the fundamental role the dog plays in the transmission of this flagellate.

In 1916 Salvador MAZZA identified T. cruzi in circulating blood of young dogs in the Province of Jujuy ${ }^{11}$. and characterized the transplacentary transmission in this host by following infected females and their youngsters ${ }^{12}$.

11 This work was supported by a grant from TDR WHO UNDP Bank

(2) Professional in Research of the Instituto Nacional de Diagnostico e Investigacion de la Enfermedad de Chagas "Doctor Mario Fatala Chaben" (I.N.D.I.E.C.H.)

(3) Director of I. N. D. I. E. C. H.

Address for correspondence: Dra. Marta Alicia Lauricella Instituto Nacional de Diagnostico e Investigacion de la Enfermedad de Chagas "Dr. Mario Fatalla Chaben". Paseo Colón. 568. Buenos Aires 1063. Argentina. 
LAURICELlA, M. A.; SINAGRA, A. J.: PAULONE, I.; RIARTE, A. R. \& SEGURA, E. L. - Natural Trypanosoma cruzi infection in dogs of endemic areas of the Argentine Republic. Rev. Inst. Med. trop. São Paulo, 31 (2): 6370,1989

In Brazil, the prevalence of infection as measured by xenodiagnosis for naturally infected dogs, was of $18.3 \%^{8}$, and in Chile of $9.3 \%^{211}$. In endemic areas of our country, the prevalence of infection detected by serology, for dogs from ur ban areas, was of $17.5 \%$. However, the highest indices $164.2 \%$ and $65.2 \%$ for xenodiagnosis and serology respectively) corresponded to dogs trom rural areas in the Province of Santiago del Este$\mathrm{ro}^{27}$.

The area chosen for this study covers a surfa. ce of $440 \mathrm{~km}^{2}$ and it belongs to the Rio Hondo County in the mid-west of the Province of San. tiago del Estero. It's a valley one $\mathrm{km}$ in width. crossed by the Dulce River and it is located between 4 to $50 \mathrm{~km}$ from the city of Termas de Rio Hondo. The zone shows the typical vegetation of the Fitogeographic Chaco Province forested with axebreakers (Aspidosperma spp and Schinopsis spp). Partial deforestation has generated a secondary formation of xerofilus shrubs (Acacia spp and Larrea spp). This area involves a rural community of approximateiy 3.000 inhabi. tants, where the serological prevalence for Cha. gas' Disease in children less than five years old is of $8 \%^{16}$. The province of Santiago del Estero belongs to a vast central region of Argentina where the absolute maximum temperatures surpass $45 \mathrm{C}$ and the relative annual humidity is less than $70 \%$; this region is also coincident with the isoline of $75 \%$ triatomine domicile infestation ${ }^{3}$.

As this rural community belongs to an area of high endemicity for Chagas' Disease, an epidemiological surveillance project consisting in the use of appropriate tools and technology to diminish the vectorial transmission through sanitary agents belorging to the same community is being implemented in this area ${ }^{16.17}$. The objective of this work is to characterize the rural canine population and to obtain information on the $\mathrm{dy}$ namics of infection by $\mathbf{T}$. cruzi. The realization of these objectives will permit the planning of control strategies on the domestic reservoirs, contributing to abolish their parasite offer to the triatomine and, hence, to man.

\section{MATERIALS AND METHODS}

\section{A - Selection of the sample:}

The study was performed with 352 dogs (D) living in 108 houses. Only those not found during two consecutive visits to the house, and those presumably dangerous to the operators were ex cluded (12/352).

The area (Fig. 1) was divided into three zones according to the distances to the city of Termas de Rio Hondo and to the structural characteristics of the houses (huts: built with indigenous materials; brick: for which industrial technology was used; and mixed: a combination of both.

The rural zone $(R)$ contained improved huts and huts in similar proportions and was the most distant to the city; the transitional ( $T$ ) zone had the three types of houses in similar proportions and the periurban $(\mathrm{Pe})$ zone had a majority of brick houses.

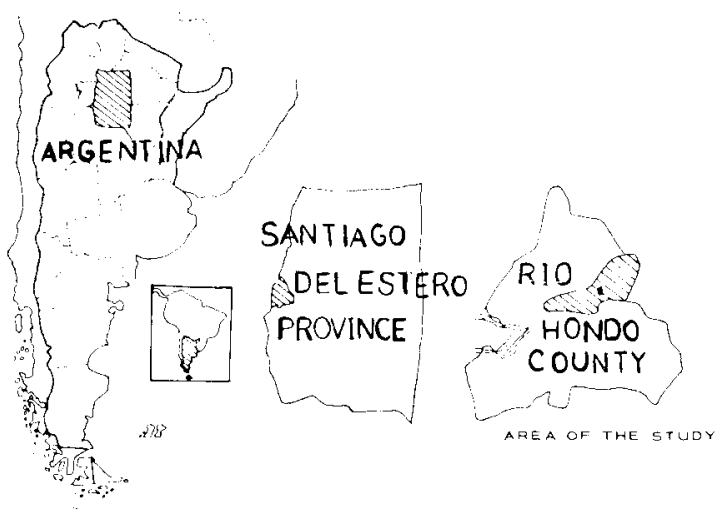

Fig. 1-Geographical location of the Rio Hondo Department. Santiago del Estero. Argentina.

A sample of the canine population that belonged to houses that had at least four triatomines (kissing bugs) during the entomological survey performed in the zone the previous year, was selected. The search methodology used was that indicated by the Chagas National Service of one man hour of searching effort using chemical irritants ${ }^{15}$. Immediately after this survey the area was sprayed with Deltamethrin and Benze ne Hexachloride

\section{$B$ - Characteristics of the population survey:}

It consisted of an inspection of the animal's aspect (sex, color, coat, particular signs, approximate weight and physical appearance) and of a questionnaire answered by its owner concer ning the animal's habits (Fig. 2). 
LAURICELlA, M. A.: SINAGRA, A. J.; PAULONE, I.; RIARTE, A. R. \& SEGURA, E. L. - Natural Trypanosoma cruzi infection in dogs of endemic areas of the Argentine Republic. Rev. Inst. Med. trop. São Paulo, 31 (2): $63-70,1989$

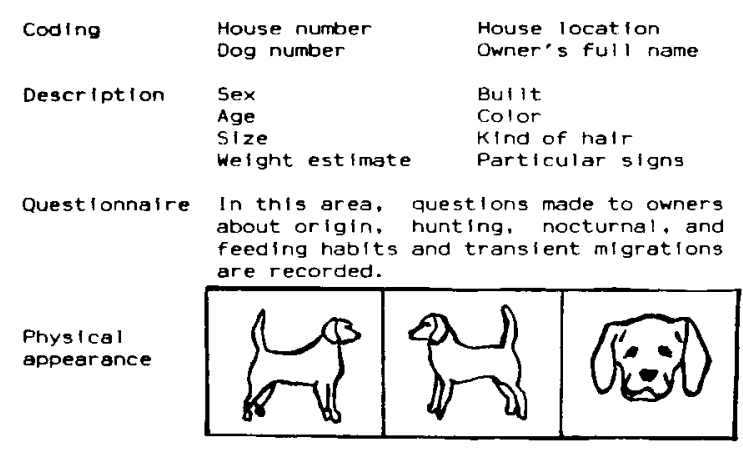

Fig. 2 - Epidemiological survey model: identification card. identikit and questionnaire.

\section{$\mathrm{C}-$ Studies performed}

On land - To detect parasitemia, xenodiagnosis was done in $340 \mathrm{D}$ using twenty T. infestans according to the methodology described previously ${ }^{2}$. Eight $\mathrm{ml}$ of non-heparinized braquiocephalic-, yugular-, or saphena-vein blood were extracted for the procurement of serum for anti T. cruzi specific antibodies on $331 \mathrm{~A}$, and looking for parasites using the STROUT enrichment me thod ${ }^{24}$, on 42 . With the purpose of detecting chronic injuries, electrocardiographic records of $45 \%$ (85 ECG) of the D older than two years of age, were obtained using a Fukuda Century electrocardiograph (SCC - 1) with a paper velocity of 2.5 $\mathrm{cm} / \mathrm{sec}$ without previous anesthesia of the animals.

The houses included the home and the peridomicile, the first constituted by the bedrooms, the gallery, and the yard or outside area next to the house, where the owners sleep in the summer. The peridomicile was represented by the kitchen, the deposit and the animal pen. The number of "kissing bugs" found in 102 houses, those found in their peridomicile, and those in the bedrooms with a previous application of piretroid stimulants, was determined.

Evaluation of infection with T. cruzi was per formed on "kissing bugs" found in bedrooms. The Average Triatomine Infestation (A.T.I.) was determined as the average of total "kissing bugs" of the house; those corresponding to bed rooms (A.T.I. ${ }_{b}$ ) and peridomicile (A.T.I.p) were also calculated.
In the laboratory - The blood obtained by conserving the sera in glycerin buffer $190 \%$ glyce rin $-10 \%$ stabilized saline solution in equal amounts) was processed daily. The blood of three $D$ chosen at random was observed daily looking for the presence of T. cruzi. For the specific antibody search in the serum of $326 \mathrm{D}$, the indirect immunofluorescence reaction was employed, using canine antigamma-globulin fluorescein tagged (Byosis S.A.). Titles accepted as positive were 16. Commercial indirect hemmagglutination (Polychaco S.A.) was also used. Discordant samples were submitted to an ELISA reaction using an antigen prepared from cultured epimas tigotes $^{25}$.

All reactions were adapted to canine sera and their sensibility was evaluated using sera of 60 parasitemic $D$ from the Moreno County (Province of Santiago del Estero) ${ }^{9}$.

\section{D - Statistical studies}

Statistical analysis of the data was done using the $\mathrm{x}^{2}$ test for analysis of frequency ${ }^{23}$. Significance was set at $P=95 \%$

\section{RESULTS}

\section{A - General characteristics of the canine popu-} lation

The canine population density was of $3.4 \mathrm{D}$ / house and only two houses lodged more than six (11 and $13 \mathrm{D}$ ). The age distribution showed a $32 \%$ diminution of the $D$ number of the 1-2 year interval with respect to $D$ of the $0-1$ year interval. Seventy five percent and $90 \%$ were be tween $0-4$ years old and 0-6 years old respectively. The number of males $(72 \%)$ was significantly higher than the number of females $(28 \%)$. Seventy seven percent was over a year old and was classified according to activity, into guardians $(68.8 \%)$, hunters $(25.7 \%)$ and goat tenders locally called "goaters" (5.5\%). See Table 1.

Seventy two percent of the dogs were born in the proximities of the houses, and the rest mostly in the cities of Termas de Rio Hondo, Santiago del Estero and some localities of the province of Tucuman; only $3 \%$ slept temporarily in the woods. Twenty nine percent of the houses 
LAURICELlA. M. A.: SINAGRA, A. J.; PAULONE, I.; RIARTE, A. R. \& SEGURA. E. L. - Natural Trypanosoma cruzi infection in dogs of endemic areas of the Argentine Republic. Rev. Inst. Med. trop. Sáo Paulo, 31 (2): 6370.1989

TABLE 1

Percentages and prevalenees of infection (PI) by serology of dogs classified aceording to their role and environment.

\begin{tabular}{|c|c|c|c|}
\hline & \multicolumn{3}{|c|}{ Role of dogs in the house } \\
\hline & guardians & hunters & goaters \\
\hline$\%$ & 68.8 & 25.7 & 5.5 \\
\hline \multirow[t]{2}{*}{ PI (e; ) } & 364 & 46.2 & 130 \\
\hline & Domicile & $\begin{array}{l}\text { Environment } \\
\text { Storage area }\end{array}$ & Pen \\
\hline$\%$ & 89.4 & 8.4 & 2.2 \\
\hline$P I(*)$ & 59.7 & 36.4 & 33.3 \\
\hline
\end{tabular}

lodged temporary workers, most of whom went to the sugar harvest in Tucuman where they stayed up to five months of the year; this way, $25 \%$ of the D abandoned the habitat transiently

The $D$ received unbalanced diets and the food was of low protein content.

Differences between the three zones were ob served: $R$ showed two distinctive characte ristics: a) the percentage of houses with temporary workers was significantly lower ( $16 \%)$ than in $\mathrm{T}(28.2 \%)$ and in $\mathrm{Pe}(40.7 \%) \mathrm{P}<0.05 ; \mathrm{b})$ the decrease in the number of $\mathrm{D}$ of the interval of 1-2 years with respect to the $0-1$ year interval was of $68.2 \%$, much greater ( $\mathrm{P}<0.05$ ) than the one registered in $\mathrm{T}(34.5 \%)$ and in $\mathrm{Pe}(12.5 \%)$. However, there were no differences between the parameters of $\mathrm{T}$ and $\mathrm{Pe}$.

\section{$B$ - Characteristics of the infection by $T$. cruzi}

The prevalence of parasitemic infection as seen by xenodiagnosis (Px), was of $19.4 \%$ with no differences between males $(20.1 \%)$ and females $(17.8 \%)$. Forty six percent of the houses had at least one $\mathrm{D}$ with positive xenodiagnosis and in only one of 42 blood samples. T. cruzi was detected by the STROUT method. This sample belonged to a nine month old $D$ that lived in the Pe area. The percentages of parasitemic dogs according to age intervals increased with each age group, and in those older than ten years old an important increment with respect to the younger ones was observed (Table 2 ).

Almost thirty four percent $(33.8 \%)$ of the D were reactive for specific anti $\mathbf{T}$. cruzi antibodies
TABLE 2

Age specific prevalences rates of seropositivity and $T$. cruzi parasitemia in dogs.

\begin{tabular}{lrrrrr}
\hline & \multicolumn{6}{c}{ Dogs examined by age groups } \\
\hline Ages & 0.4 & 59 & $10-14$ & 1519 & Total \\
\hline \# dogs examined & 279 & 45 & 12 & 4 & 340 \\
\# dogs xenopos. & 45 & 13 & 6 & 2 & 66 \\
\# dogs seropos. & 78 & 27 & 8 & 2 & 115 \\
PXr, & 16.1 & 28.9 & 50.0 & 50.0 & 19.4 \\
Pi & 28.0 & 60.0 & 66.7 & 50.0 & 33.8 \\
Px Pis & 0.58 & 0.48 & 0.75 & 1.0 & 0.57 \\
\hline
\end{tabular}

(:) Prevalence rates of infection by xenodiagnosis

(\# dogs xenopos.)

\# dogs examined

1* Prevalence rates of infection by serology

(\# dogs seropos.)

\# dogs examined

(*) Parasitological serological correlation

(\# dogs xenopos.)

\# dogs seropos.

and no differences were observed in the preva lences of infection by serology ( $\mathrm{P}$ i) between $\mathrm{ma}$ les $(35.5 \%)$ and females $(32.2 \%)$. No differences were seen in $\mathrm{Pi}_{(\mathrm{Pe})}=30.0 \%, \mathrm{Pi}_{(\mathrm{T})}=33.0 \%$, and $\mathrm{Pi}_{\mathrm{R}\}}=40.2 \%$. The $\mathrm{Pi}$ for the different $\mathrm{D}$ subgroups classified according to their environment and activity in the house were determined. The $\mathrm{Pi}$ of the hunters and guardians resulted significantly greater than those of the goaters $(\mathrm{P}<$ 0.05 ), and the $\mathrm{Pi}$ of the dogs that slept in the houses was significantly greater than of those which slept in the peridomicile $(\mathrm{P}<0.05$ ) (Table $1)$.

The study of the dynamics of infection revealed that $50 \%$ of the serologically reactive $\mathrm{D}$ contract infection before they reach five years of age. The parasitologic-serological correlation for all the D was of $57.7 \%$, and of $70 \%$ for the first year of life, showing a similar tendency to that observed for the age-specific parasite recovery.

Five electrocardiograms, either had evidences of conduction disorders, incomplete blockade of the right branch, left anterior hemiblockade, or both. Four of the five animals were parasitemic, all of them with positive serology.

The A.T.I. of 102 houses was of $43+42.9$ "kissing bugs" per house. Ninety nine percent of the houses had triatomines in bedrooms (A.T. $I_{\cdot b}=25+25.4$ ) and $58 \%$ of the houses had "kis 
LAURICELlA, M. A.; SINAGRA, A. J.; PAULOnE, I.; RIARTE, A. R. \& SEGURA, E. L. - Natural Trypanosoma cruzi infection in dogs of endemic areas of the Argentine Republic. Rev. Inst. Med. trop. Sâo Paulo, 31 (2): $63-70,1989$

sing bugs" in the peridomicile (A.T.I.p $=28+$ 32.3 . On the other hand, out of $66 \%$ of the bedroom-insects examined, $30 \%$ of them were infected with $\mathbf{T}$. cruzi (Table 3 ).

Area $\mathrm{R}$ showed distinctive characteristics with respect to infection patterns. Significant differences were observed ( $\mathrm{P}<0.05$ ) in $\mathrm{Px}$ of area $\mathrm{R}(30.5 \%)$ with respect to that of $\mathrm{T}(17.1 \%)$ and of $\mathrm{Pe}(16.2 \%)$ for similar $\mathrm{Pi}$ in all areas. Furthermore, the difference in the percentage of insects infected with $\mathbf{T}$. cruzi found in the bedrooms of the $\mathrm{R}$ area $(39.7 \%)$ with respect to those of $\mathrm{T}$ $(25.2 \%)$ and of $\mathrm{Pe}(27.8 \%)$, was significantly different ( $\mathrm{P}<0.05$ ) (See Table 3 ). There were no differences between the parameters of $\mathrm{T}$ and $\mathrm{Pe}$.

\section{DISCUSSION}

The subdivision of this area according to increasing distances to an urban conglomerate had the purpose to evaluate the influence of the environment on T. cruzi transmission. As is frequent in rural areas, a transition of huts to brick houses as the distance to the city diminished, was observed. Taking into account that the highest prevalences of seroreactivity are usually seen in residents of non-plastered houses ${ }^{13}$, it was not surprising to observe a characteristic epidemiological profile in this rural area. The parameters of the canine population and the characteristics of infection by $\mathbf{T}$. cruzi in the rural area showed differences with those of the remaining areas. There was a greater proportion of cubs than adults, a more sedentary population, higher prevalences of infection as seen by xenodiagnosis in the dogs and the highest proportion of $\mathbf{T}$. cruzi-infected insects in the bedrooms. The high number of dogs less than one year compared to the rest, is an evidence of the difficulties that this population has to overcome in the rural area, such as malnutrition, dehydra tation, parasitism and its consequences, which impinge upon the health of the animals. How ever, the possibility that in this area, infection by $\mathbf{T}$. cruzi could well be another cause of the death of the puppies must be considered.

In the rural area, significant increases in the number of houses with sedentary residents du ring the whole year were detected, the migration to the sugar-cane harvest in Tucuman is an spo radic fact, in contrast to what is observed in the periurban area where over $40 \%$ of its population has migratory habits. In a house where temporary migration of its human and animal inhabitants occurs, the triatomine population could be modified because of lack of ingesta; however, this hypothesis needs to be confirmed. The detection of chagasic infection observed in Chilean sedentary paleoindian tribes, which were formerly nomads and had Bolivia as their dispersion center, would support this hypothesis ${ }^{21}$.

The highest prevalences of infection as measured by xenodiagnosis in dogs, and the highest proportion of bedroom insects infected with $\mathbf{T}$. cruzi were observed in the rural area. The correlation between levels of triatomine infestation and parasitemia detected, agrees with that ob served in dogs of other endemic areas of Argen tina ${ }^{27,28}$ and Brazil ${ }^{14}$.

It is not possible to infer from this work if the infectivity by $\mathbf{T}$. cruzi in domicile triatomines influences the prevalences of infection in dogs or vice versa. However, the influence of this reservoir in the domestic cycle is undeniable, evidenced by the higher indices of seroreactivity in children who live in houses with infected ani mals ${ }^{14}$ and the high frequency of domiciliary tria tomines which feed in $\operatorname{dog} s^{26.28}$.

TABLE 3

Detection of infection by T. cruzi in domiciliary triatomines found in bedrooms.

\begin{tabular}{lcccc}
\hline Area & rural (R) & transitional (T) & periurban (Pe) & Total \\
\hline \# houses & 22 & 48 & 32 & 102 \\
$\begin{array}{l}\text { \% of infected bedroom } \\
\text { "kissing bugs" }\end{array}$ & 39.7 & 25.2 & & 30.0 \\
& $(184 / 462)$ & $(196 / 778)$ & $(103 / 370)$ & $(483 / 1610)$ \\
\hline
\end{tabular}


LAURICFLLA, M. A.; SINAGRA, A. J.: PAULONE, I.; RIARTE, A. R. \& SEGURA, E. L. - Natural Trypanosoma cruzi infection in dogs of endemic areas of the Argentine Republic. Rev. Inst. Med. trop. São Paulo, 31 (2): 63-70, 1989

In this work the parasitological-serological correlation goes from $58 \%$ in young animals to $100 \%$ in senile dogs, as it was also observed in other areas of Santiago del Estero ${ }^{6}$. This is unlike humans where this correlation descends from $100 \%$ in children less than four years old to $33 \%$ in adults ${ }^{8}$, and is an indication of differences be tween the parasitological profiles of humans and dogs. Higher chances of reinfection in dogs, due to their closer contact with the triatomines ${ }^{28}$. and the peculiar characteristics of their immune system, could be the cause for these differences.

The numeric differences observed between males and females suggest an artificial selection made by their owners, frequent in rural areas. The similar prevalences of infection by xenodiagnosis and serology in both sexes indicate a similar susceptibility to infection, as seen in humans, in contrast to that observed in experi mental infections of mice with the Brazil strain of $\mathbf{T}$. cruzi ${ }^{18}$ or in certain strains of rats ${ }^{19}$.

The evidence that one out of two houses of the study area had at least one parasitemic dog. justifies the investigation of the infection mecha nisms of this reservoir, evaluating the incidence of perinatal 12 and "contaminant" transmission". The high proportion of perinatally infected pup pies studied by MAZZA ${ }^{12}$ and the contaminant mechanisms of infection observed in animals ${ }^{4}$ bespeak for the evaluation of its influence specially in desinsectized houses.

The unmistakable confirmation that this re servoir contributes blood and flagellates to the triatomine population, supports the implementation of measures tending to block its influence by means of the development of vaccines ${ }^{22}$ or the use of chemotherapy. ${ }^{1 .}$.

\section{RESUMO}

Infecçāo natural pelo Trypanosoma cruzi em cáes de áreas endêmicas da República Argentina.

Estudou-se a dinâmica populacional e a pre. valência de infecção chagásica de 352 cães vivendo em 108 moradias rurais infestadas por triatomineos. A área foi dividida em três setores de acordo com suas crescentes distâncias em rela ção a um povoado urbano. Cada animal foi identificado mediante suas características particu lares, e seus donos deram informaçōes a respeito de seus hábitos. As prevalências de infecçāo fo ram determinadas por sorologia, correlação pa rasitológica-sorológica, percentual de traçados eletrocardiográficos alterados e o percentual de moradias com cães parasitados.

A área rural mostrou um padrão caracterís tico de infecção por T. cruzi e observaram-se diferenças nos parâmetros de população canina em relação às restantes áreas: maior proporção de filhotes, maior população humana e canina sedentárias, maiores prevalências de infecção por xenodiagnóstico em cães e maior proporçāo de barbeiros infectados com T. cruzi nos cômo dos da casa.

Supōe-se que as características sedentárias da população humana desta área rural é fundamental para a oferta de sangue para as popula çōes triatomineas, e a elevada porcentagem de cães parasitemicos dessa área contribui para o aumento de barbeiros infectados com $\mathbf{T}$. cruzi encontrados nos quartos de dormir.

\section{ACKNOWLEDGMENTS}

We thank Dr. Roberto Chuit for his professional help in the area, and Mr. Domingo Luna and Mr. Griseldo Roldan for technical collabo ration. We also thank Dr. Mirta Carlomagno for editorial assistance. Our deepest thanks go to Dr. Carlos Del Prado for the photographs.

\section{REFERENCES}

1. CABEZA MECKERT, P. M.; CHAMBO, J. G. \& LA GUENS, R. P. - Modification of the pattern of infection and evolution of cardiopathy in experimental Chagas di sease after treatment with immunosuppressive and trypa nocidal drugs. Medicina (B. Aires), 48: $711,1988$.

2. CERISOLA, J. A.; RHOWEDDER, R.; SEGURA, E, L.; DEL PRADO, C. E ; ALVAREZ, M. \& MARTINI, G. W - El xenodiagnóstico: normalización utilidad. Premio Geigy 1974. Buenos Aires. Ministerio de Bienestar Social. Secretaria de Salud Pública, 1974.

3. CURTO DE CASAS, S. I. - Problemática geográfica de la endemia chagásica y técnica para su estudio. Factores biológicos y cológicos en la enfermedad de Chagas. In CARCAVALLO, R. U.; RABINOVICH, J. E. \& TONN, R. J., ed. - Epidemiologia-vectores. Buenos Aires. Servicio 
LAURICELla, M. A.; SINAGRA, A. J.; PAUlone, I.; Riarte, A. R. \& SEgurA, E. L. - Natural Trypanosoma cruzi infection in dogs of endemic areas of the Argentine Republic. Rev. Inst. Med. trop. Saao Paulo, 31 (2): 63-70, 1989 .

Nacional de Chagas; Ministerio de Salud y Acción Social. 1985. Cap. 4 , p. $31-47$

4. DIAZ UNGRIA, C. - Experimental study of T. cruzi in dogs and other vertebrates. The problem of transmission. Kasmera, 3: 73-88, 1968 .

5. GORODNER, O. L. Z. de; MENDIVIL, G. T: RISSO, A.: RISSO, J. J.; PETRAGLIA, G.; DE FRANCESCO. C. \& BUSTAMANTE, A. - Enfermedad de Chagas natural en perras. Estudios serológicos, anatomopatológicos y electrocardiográficos de la fase crónica indeterminada de la infección. Medicina (B. Aires), 45: 535-538, 1985.

6. GURTLER, R. E.; SOLARZ, N. D.; LAURICELLA, M. A.; HAEDO, A. S.: PIETROKOVSKI. S.: ALBERTI, A. A \& WISNIVESKY-COLLI, C. - Dynamics of transmission of Trypanosoma cruzi in a rural area of Argentina. III Persistence of $\mathbf{T}$. cruzi parasitemia among canine reser voirs in a two-years follow-up. Rev. Inst. Med. trop. S. Paulo, 28: 213-219, 1986.

7. HABERNKORN, A. \& GONNERT. R. - Animal experi mental investigation into the activity of Nifurtimox against T. cruzi. Arzneim. Forseh, 22: 1570-1582, 1972

8. HOFF, R.; MOTT, K. E.; SILVA, J. F.; MENEZES. V.: HOFF. J. N.; BARRETT. T. V. \& SHERLOCK, I. - Preva lence of parasitemia and seroreactivity to $\mathbf{T}$. cruzi in a rural population of northeast Brazil. Amer. J. trop. Med. Hyg., 28: 461-466, 1979

9. LAURICELLA, M. A.; WISNIVESKY COLLI, C.: RUIZ, A. M. SOLARZ, N.; BUJAS, M. A.; \& SEGURA, E. L - Estudio serológico de poblaciones. In: CONGRESO ARGENTINO DE PROTOZOOLOGÍA Y REUNIÓN SO BRE ENFERMEDAD DE CHAGAS, 1., Huerta Grande, Córdoba, 1984

10. LAURICELLA, M. A.; RIARTE, A. R.; LAZZARI, J.; BA ROUSSE, A. \& SEGURA, E. L. - Enfermedad de Chagas en perros experimentalmente infectados con T. cruzi. Medicina (B. Aires), 46: 195-200, 1986.

11. MAzzA, S. - Observación de infección espontanea del perro por el Schizotrypanum cruzi. Rev. Soc. argent. Biol., 2: $33-41,1926$

12. MAZZA, S - Frecuencia e importaneia de la infección natural de perros y gatos por $\mathbf{S}$. cruzi y cuestión de la herencia del mismo $\in$ in los primeros animales. In: REU. NIÓN DE LA SOCIEDAD ARGENTINA DE PATOLOGÍA REGIONAL, 9., Mendoza, 1935. v. 1, p. 412417

13. MOTT, K. E.; MUNIZ, T. M.; LEHMAN, J. S.; HOFF, R. MORROW, R. H.; SILVA DE OLIVEIRA, T.; SHER LOCK, I. \& DRAPER, C. C. - House construction, triato mine distribution and household distribution of seroreac tivity to $\mathbf{T}$. cruzi in a rural community in Northeast Brazil Amer. J. trop. Med. Hyg., 27: 1116-1122, 1978.

14. MOTT, K. E.; MOTA, E. A.; SHERLOCK, I.; HOFF. R. MUNIZ, T : OLIVEIRA, T. \& DRAPER, C. C. - T. cruzi infection in dogs and cats and household reactivity to T. eruzi in a rural community in the Northeast Brazil Amer. J. trop. Med. Hyg., 27: 1123-1127, 1978
15. NORMAS TECNICAS Y DE PROCEDIMIENTOS PARA LA LUCHA QUIMICA CONTRA EL VECTOR DE LA ENFERMEDAD DE CHAGAS. Buenos Aires, Publicación del Servicio Nacional de Chagas de la República Argentina, Ministerio de Salud Publica y Medio Ambiente, 1 (1): $29-34$, Oct., 1983

16. PAULONE, I.; CHUIT, R.; PEREZ, A.; WISNIVESKY COLLI, C. \& SEGURA, E. L. -- Field research on an epide miological surveillance alternative of Chagas disease transmission: the Primary Health Care ( $\mathrm{PHC}$ ) strategy in rural areas. Rev. argent. Microbiol., 20 (suppl): 103-105, 1988.

17. PEREZ, A.; LANSETTI, J.C.; DE RISSIO, A. M.; PAULO NE, I.; CHUIT, R. \& SEGURA, E. L. - Seguimiento longi tudinal de la población de niños de $0-5$ años bajo vigilancia epidemiológica para la Enfermedad de Chagas en Termas de Rio Hondo, Sgo. del Estero. In: CONGRESO ARGENTINO DE PROTOZOOLOGÍA Y REUNIÓN SOBRE EN. FERMEDAD DE CHAGAS, 2., La Falda, Córdoba, 1987. p. 46 .

18. POSTAN, M.: MC DANIEL, J. P. \& DVORAK, J. A. Studies of $\mathbf{T}$. cruzi clones in inbred mice. II Course of infection of C57BL $/ 6$ mice with single-cell-isolated stocks. Amer. J. trop. Med. Hyg., 33: 236-238, 1984.

19. REVELLI, S. S; AMERIO, N; MORENO, H. S ; VALEN TI, J. L.; BALBARREY, H. \& MORINI, J. C. - Enfer medad de Chagas crónica en la rata. Características sero logicas, electrocardiográficas e histopatologicas. Medicina (B. Aires), 40 (suppl. 1): 69-76, 1980

20. ROJAS, A.; SOTELO, J. M.; VILLARROEL, F. \& CON TRERAS, C. M. -.. La importancia del perro y el gato en la epidemiologia de la Enfermedad de Chagas. Bol. chil. Parasit., 28: 42 43. 1973.

21. ROTHHAMMER, F. - Chagas disease in Chilean mummies. Parasit. Today, 1 (1): 3, 1985

22. RUIZ, A. M.; ESTFVA. M.: RIARTE, A ; SUBIAS, E. \& SEGURA, E. L. - immunuprotection of mice against $\mathbf{T}$. cruzi with a lyophilized flagellar fraction of the parasite plus adjuvant. Immunol. Lett., 12: 1-4, 1986.

23. SOKAL, R. R. \& ROHLF, F. J. - Introduction to biostatistics. San Francisco, W. H. Freeman \& Co., 1969

24. STROUT, R. G. - A method for concentrating hemoflag ellates. J. Parasit., 48: 100, 1962

25. VOLLER, A.; DRAPER, C. C.: BIDXELL, D. E. \& BAR. TLETT, A - Microplate enzyme-linked immunosorbent assay for Chagas' disease. Lancet, 1: 426-428, 1975.

26. WISNIVESKY-COLLI, C.; GURTLER, R. E.; SOLARZ, N. D.; SALOMON, D. \& RUIZ, A. M. - Feeding patterns of $T$. infestans (Hemiptera: Reduviidae) in relation to transmission of American Trypanosomiasis in Argentina. J. med. Entomol., 19: 645-654, 1982.

27. WISNIVESKY COLLI, C.; GURTLER, R. E.; SOLARZ, N. D.; LAURICELLA, M. A. \& SEGURA, E. L. - Epidemiological role of humans, dogs and cats in the transmission of $\mathbf{T}$. cruzi in a central area of Argentina. Rev. Inst. Med. trop. S. Paulo, 27: 346-352, 1985. 
LAURICELla, M. A; SINAGRA, A. J.; PAULONE, I.; RIARTE, A. R. \& SEGURA, E. L. - Natural Trypanosoma cruzi infection in dogs of endemic areas of the Argentine Republic. Rev. Inst. Med. trop. Sáo Paulo, 31 (2): 6370.1989.

28. WISNIVESKY-COLLI, C.: RUIZ, A. M.: LEDESMA, O GURTLER, R. E.; LAURICELlA, M. A.: SALOMON, D. O.; SOLARZ, N. \& SEGURA, E. L. - Ecologia doméstica de la Trypanosomiasis americana: perfil alimentario del T. infestans en un area rural de la provineia de Santiago

del Estero. Argentina. Rev. Soc. bras. Med. trop., 20: 31 -39, 1987 .

Recebido para publicaçāo em 23/8/1988. 